\title{
Marine Viruses: the Beneficial Side of a Threat
}

\author{
Arturo Sánchez-Paz • Adriana Muhlia-Almazan • \\ Reinhard Saborowski • Fernando García-Carreño • \\ Gaurav Sablok • Fernando Mendoza-Cano
}

Received: 19 September 2013 / Accepted: 21 August 2014

(C) Springer Science+Business Media New York 2014

\begin{abstract}
Marine viruses are ubiquitous, extremely diverse, and outnumber any form of life in the sea. Despite their ecological importance, viruses in marine environments have been largely ignored by the academic community, and only those that have caused substantial economic losses have received more attention. Fortunately, our current understanding on marine viruses has advanced considerably during the last decades. These advances have opened new and exciting research opportunities as several unique structural and genetic characteristics of marine viruses have shown to possess an immense potential for various biotechnological applications. Here, a condensed overview of the possibilities of using the enormous potential offered by marine viruses to develop innovative products in industries as pharmaceuticals,
\end{abstract}

All authors contributed equally to this work.

A. Sánchez-Paz $(\bowtie) \cdot$ F. Mendoza-Cano

Laboratorio de Referencia, Análisis y Diagnóstico en Sanidad Acuícola, Centro de Investigaciones

Biológicas del Noroeste S. C. (CIBNOR), Calle Hermosa 101. Col. Los Ángeles, 83106 Hermosillo,

Sonora, Mexico

e-mail: asanchez04@cibnor.mx

F. Mendoza-Cano

e-mail: fmendoza@cibnor.mx

A. Muhlia-Almazan

Bioenergetics and Molecular Genetics Lab, Centro de Investigación en Alimentación y Desarrollo (CIAD),

Hermosillo, Sonora, Mexico

e-mail: amuhlia@ciad.mx

R. Saborowski

Alfred Wegener Institute for Polar and Marine Research, Functional Ecology, 27570 Bremerhaven, Germany

e-mail: reinhard.saborowski@awi.de

F. García-Carreño

Biochemistry Laboratory, Centro de Investigaciones Biológicas del Noroeste (CIBNOR), La Paz, Baja

California Sur, Mexico

e-mail: fgarcia@cibnor.mx

G. Sablok

Department of Biodiversity and Molecular Ecology, IASMA Research and Innovation Centre, Fondazione Edmund Mach, Via E. Mach 1, 38010 San Michele All'Adige, Trento, Italy

e-mail: sablokg@gmail.com 
environmental remediation, cosmetics, material sciences, and several others, is presented. The importance of marine viruses to biotechnology should not be underestimated.

Keywords Biotechnology $\cdot$ Marine viruses $\cdot$ Remediation $\cdot$ Cosmetics $\cdot$ Aquaculture $\cdot$ Delivery vehicles

\section{Introduction}

Over the last 120 years, viruses have been recognized as causal agents of infectious illness and death, and consequently its study has become a major research topic, as confirmed by the number of scientific articles published during the last 50 years (Fig. 1a). However, research conducted in the last years has dramatically broadened our knowledge and has opened new perspectives in our view on viruses in basic and, particularly, applied disciplines. The latter is documented in the remarkable increase in the number of scientific publications dealing with the application of viruses in biotechnology (Fig. 1b).

Since their discovery at the end of the 1970s [1], marine viruses have attracted considerable attention as well, mainly because of their economic and ecological negative impact on both farmed and wild marine species (Fig. 1c). The ability of marine viruses to infect a broad range of evolutionary divergent groups of marine organisms as bacteria, protists, molluscs, crustaceans, cnidarians, reptiles, fishes, and mammals, has been largely documented over the years [2], and actually, an ample literature exists on this topic. However, despite a number of studies characterizing certain unique properties of interest for both basic research and industrial applications, these viruses have remained largely unexplored (Fig. 1d). This is surprising as
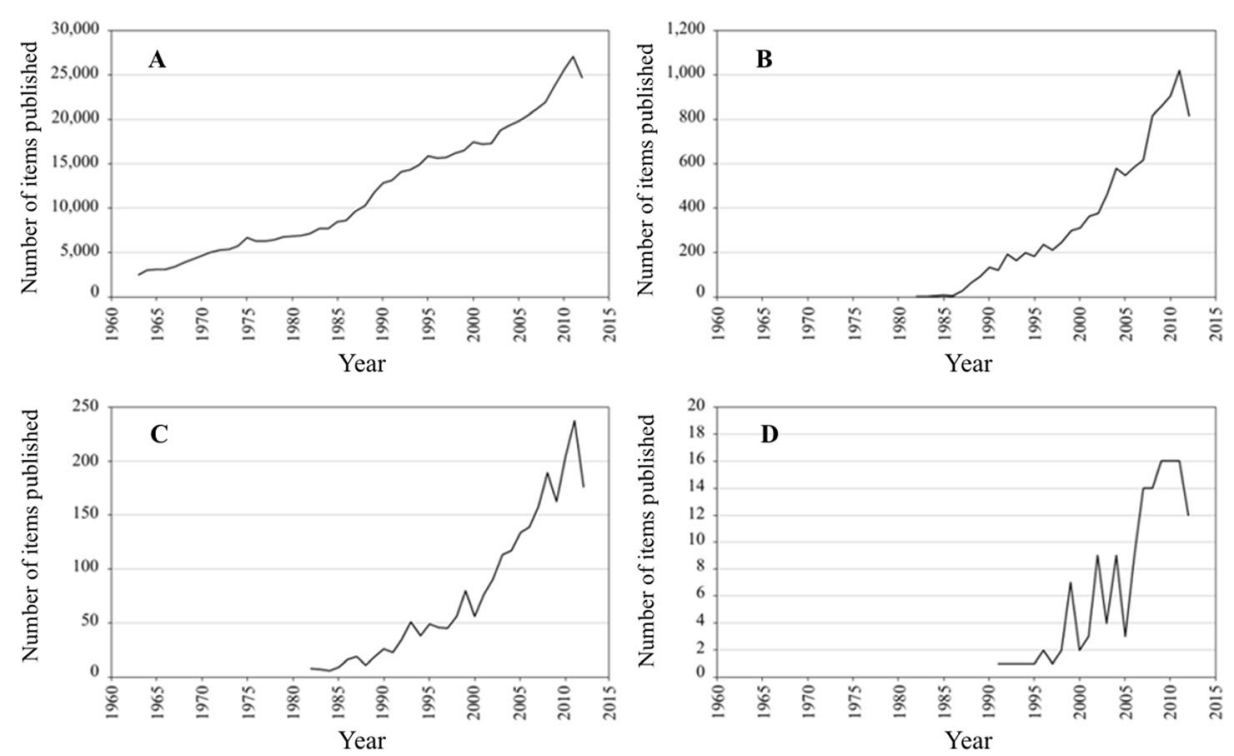

Fig. 1 Total number of peer-reviewed articles published until 2012, containing the terms: viruses (a), viruses AND biotechnology (b), marine viruses (c), and marine viruses AND biotechnology (d). The PubMed database was used to search the peer-reviewed articles containing the above-mentioned subjects from 1963 (for viruses), 1982 (for viruses AND biotechnology), 1982 (for marine viruses), and 1991 (for marine viruses AND biotechnology) to 2012 
marine viruses represent the most abundant biological entities inhabiting the world's oceans (Fig. 2) and are recognized as ecologically important components of the marine environment [3-5] as they accelerate the transformation of particulate nutrients to a dissolved available state, for reutilization by microbial communities (Fig. 3). Moreover, marine viruses are now considered as the greatest reservoir of unexplored genetic diversity on our planet [5]. In this context, it must be stressed that the majority of the genetic properties of marine viruses (encoding an enormous supply of biochemical and physiological information) are functionally unknown [6], positioning marine viruses as suitable sources for the development of new and versatile tools for biotechnology.

Research on the potential applications of marine viruses in various biotechnological processes is currently a fascinating emerging topic that is remarkably understudied, and the gap between basic research on marine viruses and the applied side of it is rapidly widening. Recent findings, however, have exhibited a wide spectrum of novel characteristics in marine viruses that may provide major biotechnology breakthroughs and possibilities in a number of different fields like medicine, material science, and cosmetics. Here, we draw attention toward marine viruses as a novel source for biotechnological products, and we briefly speculate on the realistic potential for their application.

\section{Marine Viruses and Environmental Remediation}

Over-enrichment of aquatic systems with nutrients, principally phosphorus (P), results in a problematic condition known as eutrophication [7, 8], a widespread and growing problem in which water quality is compromised [9]. Recently, the concept of planetary boundaries was proposed to define the human-determined acceptable levels of key global variables $[10,11]$. In the case of $\mathrm{P}$, it has been found that the discharge levels of $\mathrm{P}$ from freshwater into the oceans already exceed the proposed boundary of ten times the pre-industrial level [12]. Phosphorus can reach oceanic waters through the disposal of wastewaters or as a result of runoff and leaching. It must be underlined that the use of $\mathrm{P}$ fertilizers has declined drastically across Europe and in other developed nations in the last 20 years, in contrast to the increasing demand for P fertilizers in developing countries (Fig. 4). On the other hand, large amounts of wastewaters are generated in modern industrial societies and must be treated prior to disposal into waterways. Recent estimates suggest that urban residents discharge 2-3 g P per capita per

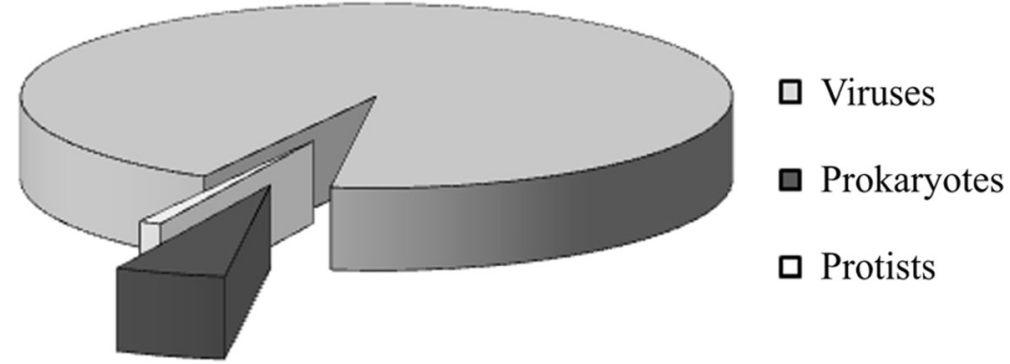

Fig. 2 Relative estimated abundance of protists, prokaryotes, (bacteria and archea) and viruses. Viruses are known to be the most abundant biological entities in the oceans, exceeding the abundance of bacteria and archaea by $\sim 15$-fold. Marine viruses comprise approximately $94 \%$ of the nucleic acid-containing particles in the oceans, while prokaryotes and protists represent only a 5 and $1 \%$, respectively. Similarly, the number of viruses in marine sediments always exceeds the total cell counts [63]. The extensive number of viruses in marine sediments highlights their impact as a controlling factor for prokaryotic mortality. Modified from [64] 


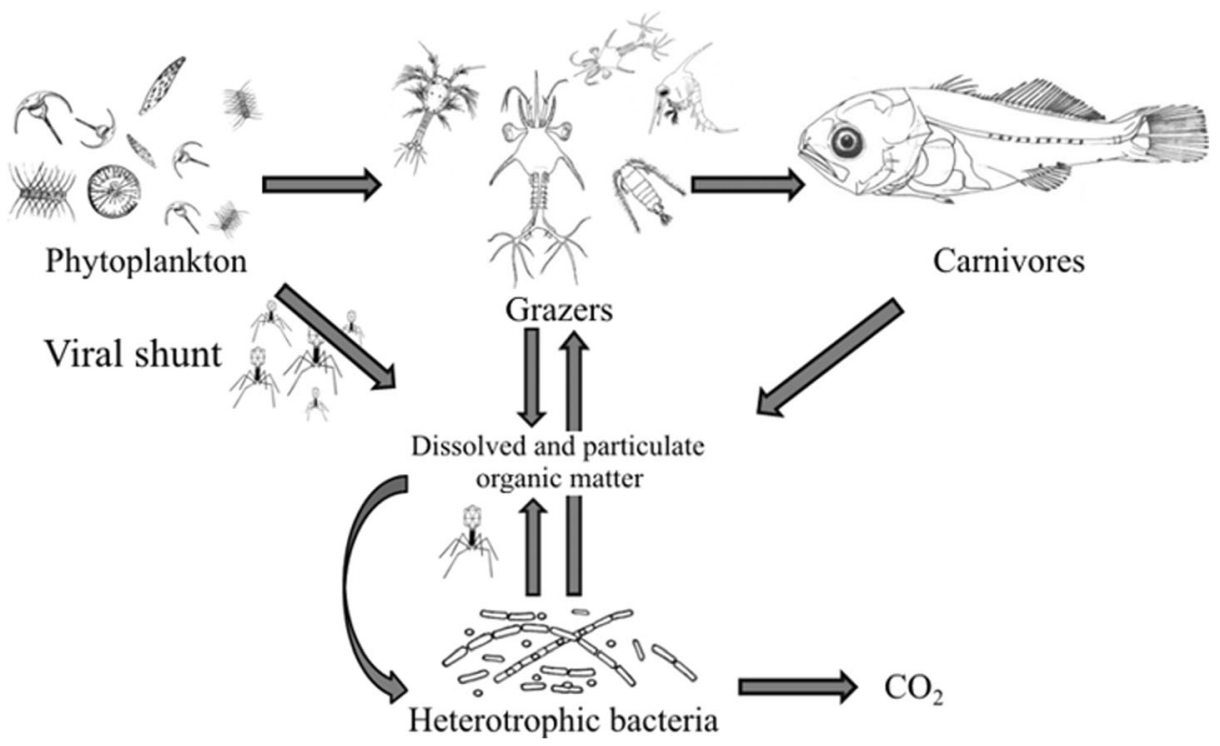

Fig. 3 Viruses are a highly important force driving the biogeochemical cycles in the ocean. Viral lysis influences the flow of carbon and nutrients from phytoplankton and bacteria to higher trophic levels in a quantitatively significant amount. Furthermore, the effect viral shunt allows the carbon from infected cells to remain as dissolved organic matter near the ocean surface, where they are assimilated by heterotrophic bacteria and released into the environment as recycled inorganic nutrients that are used again by phytoplankton. Modified from [64]

day from households [13], and that the total amount of phosphates discharged in urban wastewaters in the European Union almost reaches 1,145,000 t (in $\mathrm{P}_{2} \mathrm{O}_{5}$ equivalent) per year. Furthermore, anaerobic treatment of wastewater releases large amounts of $\mathrm{P}$, which has been implicated in cases of eutrophication of water bodies [14]. Therefore, $\mathrm{P}$ must be removed from wastewater effluents before it is returned to the environment. The current technologies to reduce $\mathrm{P}$ levels in wastewaters include chemical precipitation or physical and biological

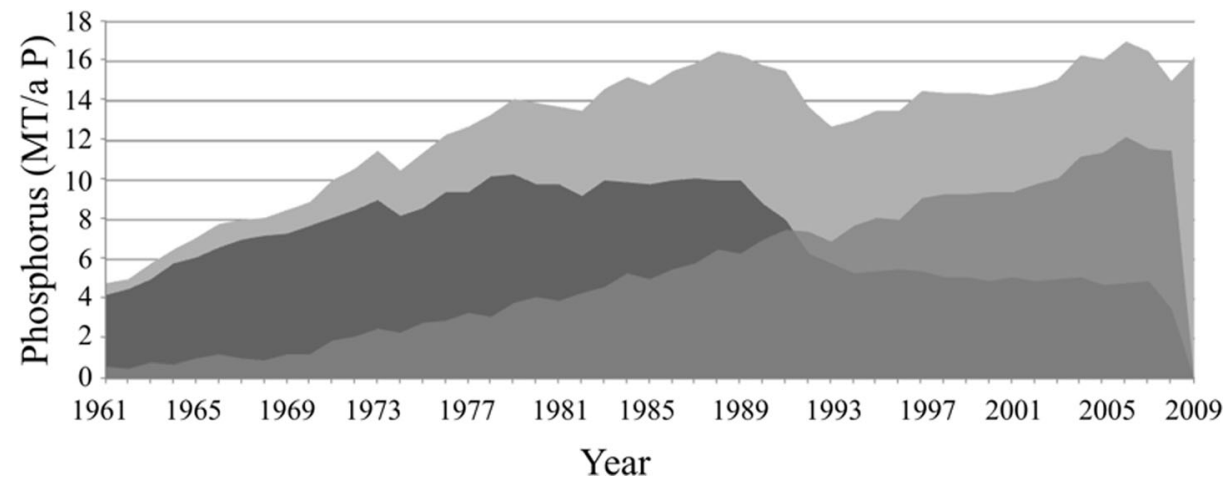

Fig. 4 World phosphorus fertilizer consumption. The amount of phosphorus fertilized consumed by Europe and other developed countries (black) decreased significantly between 1989 and 1994, while in developing countries (medium gray), the demand for P fertilizers has increased constantly. World total consumption (ligh gray) has remained relatively steady since 1981 to date. Data obtained from the International Fertilizer Industry Association (http://www.fertilizer.org/ifa/ifadata/search) 
methods. Chemical precipitation of $\mathrm{P}$ is accomplished by the addition of a coagulant, typically an iron or aluminum salt, with high efficiency and simple operation conditions [15], but this process is highly expensive [16]. The biological process, known as enhanced biological phosphorus removal (EBPR), depends on microorganisms that accumulate large quantities of $\mathrm{P}$ (as polyphosphate) intracellularly $[17,18]$. However, this system often deteriorates at low chemical oxygen demand (COD) and under aerated conditions [19, 20].

An efficient alternative in P-remediation might be provided by marine phages (including cyanophages), which are the most abundant and highly diverse, as well as largely uncharacterized, component of marine viral assemblages [21]. Several metagenomic-based approaches have led to the discovery of a large set of unrecognized open reading frames (ORFs) and a wide variety of phage-encoded genes, traditionally considered as exclusively associated to cellular genomes, involved in central metabolic pathways and key regulatory mechanisms of their hosts $[22,23]$. A recent study revealed that the genomes of two phages (cyanomyophages $\mathrm{P}-\mathrm{SSM}_{2}$ and $\mathrm{P}-\mathrm{SSM}_{4}$ ) that infect the ubiquitous marine cyanobacteria Prochlorococcus marinus contain a gene encoding for a high-affinity phosphate-binding protein (pstS) [24]. Phosphorus is an obligate requirement for the growth of cyanobacteria, but its bioavailability in environments with low absolute concentrations of nutrients is scarce. Furthermore, significant amounts of $\mathrm{P}$ are also required during the replication of the cyanophage genome. Thus, a significant increase in the expression of $p s t S$ contributes to a rapid $\mathrm{P}$ uptake in cyanophage-infected $\mathrm{P}$-starved host cells, contributing to initiate the lytic cycle under favorable conditions. It is obvious that these phages could gain a significant fitness advantage by increasing host $\mathrm{P}$ acquisition in P-limited environments [25]. Because of its high affinity for $\mathrm{P}$, this protein may contribute to applications in the area of environmental biotechnology.

A new approach for removing $\mathrm{P}$ from wastewaters is based on the expression of a heterologous phosphate-binding protein (PBP) on the surface of recombinant bacteria, a process called "bacterial surface display." In a recent study, the Escherichia coli K12 PBP was expressed and localized on the surface of an engineered strain of Pseudomonas putida. The phosphate biosorption capacity was high and reached $288 \mathrm{mg} \mathrm{L}^{-1}$ per day by $0.45 \mathrm{mg}$ of cells (dry weight). Furthermore, this P-absorption capacity was retained at an appreciable level even in heat-killed cells [26]. Accordingly, the expression of the viral high-affinity phosphatebinding protein $p s t S$ on the surface of $P$. putida, a bacterial system that remains viable under low-COD conditions, may become a highly attractive and promising solution for wastewater treatment.

\section{Marine Viruses and Cosmetics}

Another potential application of marine viruses is in the cosmetics industry. Emiliania huxleyi (Fig. 5), a worldwide distributed unicellular algal species, is capable of forming vast blooms in the open ocean, which can cover areal extents of more than $100,000 \mathrm{~km}^{2}$. During the last decade it was demonstrated that a virus, designated as EhV, was able to infect and replicate efficiently within E. huxleyi cells, and subsequently the full viral genome sequence of the strain EhV-86 was published [27, 28]. A unique feature of the EhV-86 genome is that it contains a cluster of at least seven genes encoding key components of sphingolipid biosynthesis, leading to the formation of ceramide, which seems to be expressed to enrich cell membranes and modulate the entry and release of the viral particles, controlling thus a successful infection [28, 29]. These viral genes for the biosynthesis of sphingolipids are the first found in a viral genome, and the evidence suggests that they were horizontally acquired from its host in a 
Fig. 5 A scanning electron microscope image of a Emiliania huxleyi cell. The scale bar represents $1 \mu \mathrm{m}$. Kindly provided by Dr. Jeremy R. Young (Earth Sciences, University College London)

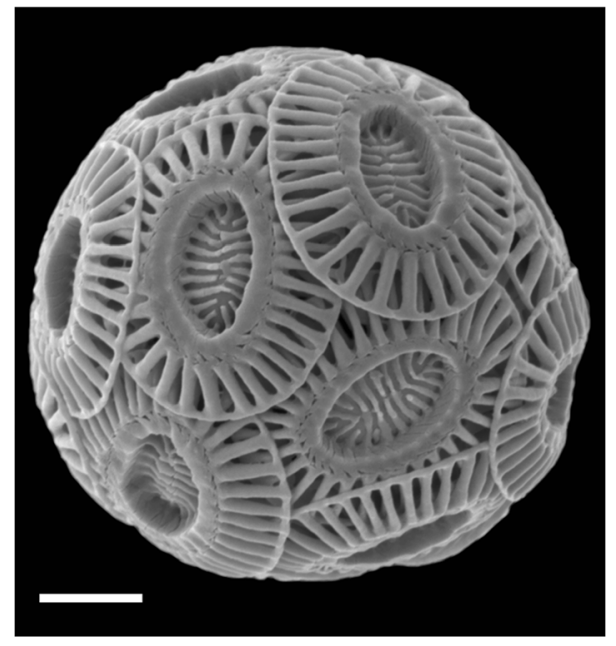

series of separate transfer events, conferring a selective advantage and increasing the fitness of this virus [30].

The ceramides, amides of fatty acids with hydroxylated long chain amines (Fig. 6), are key intermediate products in the biosynthesis and catabolism of various sphingolipids. Ceramides have been associated in the regulation of critical processes as aging, cell differentiation, apoptosis, and cell cycle arrest [31], and as key structural lipids of skin, hair, and nails of humans and animals, and due to its major role as an effective epidermal barrier against water loss [32], there has been considerable interest in these compounds as active components in the cosmetic industry [33]. Even if synthetic ceramides are now commonly used in the preparation of cosmetic products, most of these biomolecules currently used are obtained from natural sources such as bovine brain, porcine epidermal tissues, eggs, blood cells, plants, and yeast [34] (Table 1). However, these sources may cause health problems due to the potential contamination with pathogen agents as bacteria and bovine spongiform encephalopathy. Furthermore, ceramide extraction from these sources is expensive and affords low yields. Thus, the expression and production of ceramides by EhV-86 may represent a promising source of natural ceramides for use in medicines and cosmetics.

\section{Marine Viruses in Aquaculture: the Trojan Horse}

Various forms of viral diseases have been reported to infect shrimp and several other crustaceans. Among the most lethal viruses infecting shrimp, one deserves particular attention

Fig. 6 Representative chemical structure of ceramides

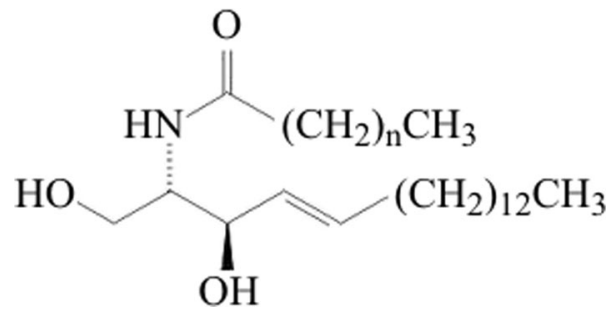


Table 1 Natural and synthetic sources of ceramides

Source

\begin{tabular}{ll}
\hline Microorganisms & - Yeast extracts \\
& - Expensive \\
Plants & - Soy bean extracts, wheat, rice seeds, spinach \\
& - Small amounts \\
Animals & Bovine brain, spinal cord, egg, skin \\
& - Potential risk of contamination by pathogen agents (i. e., BSE), expensive \\
Chemical synthesis & Various structures, improper stereochemistry, undesired residual chemicals, \\
& large amount of by-products, environmental impact \\
\hline
\end{tabular}

since outbreaks of this disease has caused social, economic, and ecological adverse impacts on many countries: the Penaeus stylirostris densovirus (PstDNV, also known as IHHNV). The PstDNV, a highly prevalent and widely distributed shrimp virus, may cause high mortality rates of above $90 \%$ among juvenile specimens of the blue shrimp P. stylirostris [35], while in the whiteleg shrimp Penaeus vannamei it has been associated with runt deformity syndrome (RDS), causing significant reduction on the growth rate and cuticular deformities as bent rostrum, blistered cuticle, bent telson, abdominal anomalies, and curly antennae [36].

The PstDNV (Fig. 7), classified as a member of the family Parvoviridae, is the smallest of the known penaeid shrimp viruses (the non-enveloped particles have a diameter of $22 \mathrm{~nm}$ ). The typical PstDNV genome is a linear non-segmented single-stranded DNA of $3.9 \mathrm{~Kb}$, and is composed by three large overlapping open reading frames (ORFs): the left ORF, the right ORF, and the middle ORF (and a potential domain of $704 \mathrm{nt}$, referred as small ORF, found on the complementary DNA strand) (Fig. 8). By analogy to the right ORF sequence from other parvoviruses, it has been suggested that it encodes the capsid protein (CP) [37]. The full-length coding region of the PstDNV-CP gene was recombinantly expressed in E. coli, and the obtained capsid protein self-assembled spontaneously into virus-like particles (VLPs) with

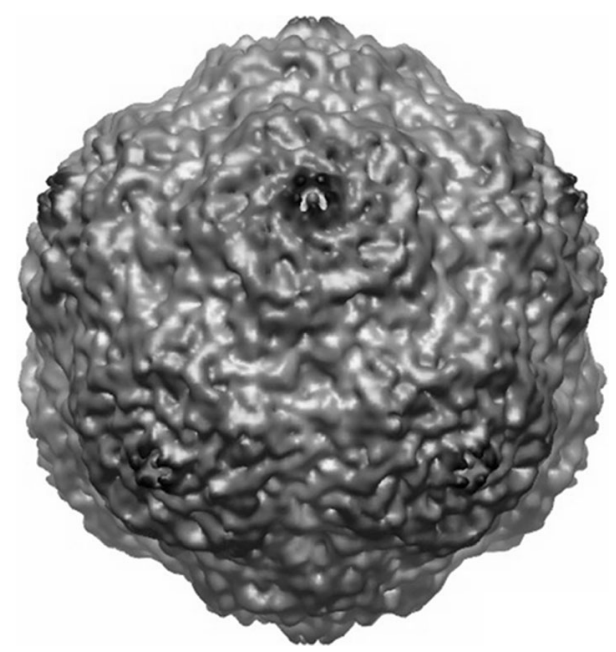

Fig. 7 A high-resolution three-dimensional structure of the recombinant PstDNV capsid showing the prominent surface features. Kindly provided by Dr. Michael G. Rossmann (Hockmeyer Hall of Structural Biology, Purdue University) 


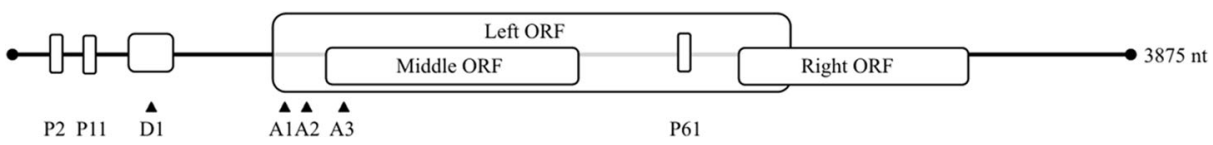

Fig. 8 Schematic representation of the genome organization of the Penaeus stylirostris densovirus (PstDNV, also known as IHHNV). The three open reading frames (ORFs; left ORF, middle ORF, and right ORF) are indicated by boxes. The predicted donor (D1) and acceptors (A1, A2, and A3) sites are represented by black triangles. The locations of the promoters (P2, P11, and P61) are represented by thin boxes. Modified from [36]

homogeneous size and a similar shape to those observed in native PstDNV particles. Furthermore, it was found that the recombinant PstDNV-VLPs are able to encapsidate substantial amounts of nucleic acids, mainly RNA with a predominant size of $0.5 \mathrm{~kb}$ and are also able to efficiently bind and enter into primary hemocytes of shrimp [38].

Currently, there are no effective approaches to prevent or reduce the deleterious impact of this viral pathogen over shrimp populations, and only few studies have been conducted to evaluate potential antiviral strategies against it. A recent report revealed that the replication of the virus was effectively reduced by the introduction of double-stranded RNA interference (dsRNAi) constructs corresponding to the PstDNV-CP in experimentally infected house crickets (Acheta domesticus). This suggests that the administration of PstDNV-specific dsRNA may provide a useful alternative against this virus in crustaceans [39]. Similar results have been obtained in shrimp treated with dsRNA designed to target virus-specific sequences. However, it must be underlined that even though the use of dsRNA to provide sequencedependent protection to shrimp against specific viruses seems promising, the major challenge to turn it into an effective therapeutic strategy is the delivery system [40]: The dsRNA is regularly administered by intramuscular injection, which would become a physically demanding task for the millions of individuals in a shrimp farm, and the necessity to design an adequate delivery system to overcome this limitation is fundamental. Thus, the PstDNV-VLPs may potentially act as an appropriate vehicle system to deliver dsRNA. Previous studies have demonstrated the use of VLPs to deliver RNAi successfully as a therapeutic approach against viral diseases. Recently, a report showed that the recombinant JC virus (JCV, a human polyomavirus) major capsid protein is a competent vector to deliver RNAi for gene therapy purposes [41].

\section{Using Marine Viruses Genetic Properties to Treat Diseases}

As a rough approximation, after infection of susceptible cells, viral transcription proceeds through an ordered cascade of events, which can be broadly divided into three sequential phases of expression: immediate-early (IE), early (E) and late (L) [42]. Products of IE genes are expressed relying primarily on host proteins and factors, and its transcription activates the expression of viral $\mathrm{E}$ and $\mathrm{L}$ genes, altering thus the functions of the host immune defense. Just as several other viruses, the white spot syndrome virus (WSSV), perhaps the most devastating virus affecting the shrimp aquaculture industry, transcribes its genome in such temporally defined manner, and to date 18 WSSV IE genes have been identified [43, 44]. Although the functions of most of the corresponding WSSV IE proteins remain unknown, many IE genes of other viruses encode multifunctional transcriptional regulators that may modulate the subsequent replicative events occurring during infection. A recent study has demonstrated a high promoter activity of the WSSV IE gene iel in Sf9 insect cells [44]. Its promoter activity for gene expression in insect cells is stronger than that of the cytomegalovirus (CMV) IE promoter, which is widely used as a strong and constitutively active promoter $[45,46]$. 
The unprecedented worldwide spread of highly pathogenic avian influenza viruses of the $\mathrm{H} 5 \mathrm{~N} 1$ strain is currently considered a global health concern that has provoked significant mortalities in poultry and wild bird's populations. Furthermore, it has caused human infections and mortality since 1997, when it first proved lethal in humans in an outbreak in Hong Kong. Vaccination of poultry has been recognized as effective in preventing virus introductions and limiting the size of outbreaks. However, the production of an inactivated influence vaccine requires the use of large amounts of embryonated eggs from a certified source, high-level biosecurity facilities, adequately trained personnel, and substantial financial resources. An attractive alternative is the use of recombinant hemagglutinin (HA) protein-based subunit vaccines [47].

The viral protein HA facilitates the entry of influenza viruses into host cells by binding to cell receptors via sialic acid (SA)-linked glycoprotein [48], and it also induces the process of membrane fusion [49]. Since HA is the major antigen on the surface of influenza viruses [50], it serves as the primary target for neutralizing antibodies.

Baculoviruses have been widely used since the early 1980s as an efficient vector system for the safe and abundant expression of recombinant proteins [51], as the post-translational modifications and protein folding systems are similar to those of mammals [52]. Furthermore, a number of genetic modifications, as the insertion of several types of promoters, have been incorporated into baculoviral vectors to enhance the expression of heterologous proteins in both insect and mammalian cells. Thus, HA from the H5N1 strain has been efficiently expressed in baculovirus under the control of the WSSV iel promoter without disrupting its authentic cleavage, hemagglutination activity, and immunogenicity, and it could be delivered into host cells to elicit a robust and specific long-term immune response. Furthermore, the WSSV iel was more efficient than the CMV IE promoter to express H5 hemagglutinin from avian influenza virus in baculovirus, providing a more powerful alternative to the preceding methods of vaccine production [45].

\section{Viruses: the Unseen Technology}

Nanotechnology has quietly, but profoundly, permeated all aspects of our daily lives. It involves the design, production or manipulation, and application of materials or structures within the size range of approximately $1-100 \mathrm{~nm}$ in length. In this scale, the physical and chemical properties of matter differ significantly from those of macroscale materials composed of the same constituent [53-55]. Investment in nanotechnology has drastically increased in the past decade, and numerous companies in a variety of areas as information, communication technologies, materials, drug development and delivery, health care, and medicine diagnostics, are already developing products that are reaching the market successfully. Global sales revenues for nanotechnology products have been estimated at $\sim$ US $\$ 16$ billion in 2012 and US\$37.3 billion in 2017, an expected compounded annual growth rate of $18.6 \%$ [56].

Various relevant features, as the self-assembly of their capsid, have contributed to the increasing interest and appreciation from the research community for viruses as biomaterials to develop functional materials, systems, and devices with nanoscale dimensions. Thus, as all viral capsids are assembled from virus-coded protein subunits, they can be modified through genetic engineering, allowing the incorporation of designed functionalities. Furthermore, the capsid of a number of viruses can be disassembled and reassembled under different conditions [57], which provide an opportunity to use viruses as nanocontainers [58].

An additional attribute of marine viruses that may also be relevant for nanotechnology is its remarkable morphological diversity of shapes and sizes. Virion morphologies include spherical, icosahedral, filamentous, rod-shaped, spindle-shaped, and tailed shapes. This variety has 
promoted the development of nanoparticles of different designs as drug carriers. It is now well recognized that the size, shape, and surface chemistry of a nanoparticle has a significant impact on their performance [59], and an arsenal of shapes may contribute to the development of nextgeneration biomaterials and devises for a wide variety of applications.

\section{Concluding Remarks and Prospects}

In contrast to other marine microorganisms, viruses that inhabit oceans and seas have not been explored for biotechnological applications. This review has depicted some novel features of marine viruses that may be translated into practical applications in health care, the environment, and industry. Of course, curiosity, intuition, integrity, and the analytical ability to recognize and connect multiple pieces of information will play key roles in the process of design and development of new and highly innovative biotechnological products. The abovementioned examples are only a few of the possible biotechnological applications of marine viruses that can be exploited commercially. However, applications of marine viruses are still limited by our limited understanding of viral diversity, host-virus interactions, virulence, emergence, transmissibility, viral dynamics, biochemical structure, and evolution. Despite the fact that over the last decade there have been substantial advances in the understanding of the biology of marine viruses, a more thorough knowledge of the genomes and transcriptomes composing viral communities inhabiting the oceans will be required to provide a wider spectrum of future biotechnological applications.

It is worth mentioning that the use of marine viruses in biotechnology depends largely on the potential health and environmental risks associated with them. There is no doubt that modern biotechnology, as any new technology, is surrounded by benefits and risks for society, and any new product derived from biotechnology must have a favorable benefit-risk balance. Of course, to exploit the full potential of viruses as valuable tools for biotechnology, biosafety issues should be considered and discussed, information on areas of risk should be provided to aid in the avoidance of these potential risks, and appropriate safety policies must be suggested to ensure the accurate diagnosis and proper handling of the potential risks of marine viruses. However, some control strategies to avoid these risks, as the methodology to construct replication-defective or movement-defective viruses, already exist [60-62].

In addition, much of the knowledge about marine viruses has been obtained as a consequence of the economic and social impact of a limited number of viral diseases affecting commercially important species, such as fishes, oysters, and shrimp. We can visualize that due to its vast diversity and genetic richness, marine viruses offer a seductive notion of a potentially vast, unexploited, and beneficial resource. Of course, it may not be surprising, given the recent findings that the genomes of many marine viruses contain putative genes encoding proteins with unknown function, to witness an exponential rise in biotechnological interest for marine viruses; particularly once the biological role of those proteins becomes elucidated. As our scientific knowledge on marine viruses progresses, we would be witnessing "the viruscence of biotechnology."

Acknowledgments This work was financially supported by the Consejo Nacional de Ciencia y Tecnología (CONACyT), México, for grant 102744 (to ASP). We would like to extend a special thank to Dr. Jeremy R. Young (Earth Sciences, University College London) and Dr. Michael G. Rossmann (Hockmeyer Hall of Structural Biology, Purdue University) for providing the scanning electron microscope image of a Emiliania huxleyi cell and the high-resolution three-dimensional structure of the recombinant PstDNV capsid, respectively. We also would like to thank Trinidad Encinas of the Laboratorio de Referencia, Análisis y Diagnóstico en Sanidad Acuícola (CIBNOR, Hermosillo). 


\section{References}

1. Torrella, F., \& Morita, R. Y. (1979). Applied and Environmental Microbiology, 37, 774-778.

2. Munn, C. B. (2006). Journal of the Marine Biological Association of the United Kingdom, 86, 453-467.

3. Bidle, K. D., \& Vardi, A. (2011). Current Opinion in Microbiology, 459, 207-212.

4. Rohwer, F., \& Thurber, R. V. (2009). Nature, 459, 207-212.

5. Suttle, C. A. (2005). Nature, 437, 356-361.

6. Hurwitz, B. L., \& Sullivan, M. B. (2013). PLoS One, 8, e57355.

7. Bennett, E. M., Carpenter, S. R., \& Caraco, N. F. (2001). BioScience, 51, 227-234.

8. Schindler, D. W. (1977). Science, 195, 260-262.

9. Johnson, P. T. J., Chase, J. M., Dosch, K. L., Hartson, R. B., Gross, J. A., Larson, D. J., Sutherland, D. R., \& Carpenter, S. R. (2007). Proceedings of the National Academy of Sciences USA, 104, 15781-15786.

10. Rockström, J., Steffen, W., Noone, K., Persson, A., Chapin, F. S., Lambin, E. F., Lenton, T. M., Scheffer, M., Folke, C., Schellnhuber, H. J., Nykvist, B., de Wit, C. A., Hughes, T., van der Leeuw, S., Rodhe, H., Sörlin, S., Snyder, P. K., Costanza, R., Svedin, U., Falkenmark, M., Karlberg, L., Corell, R. W., Fabry, V. J., Hansen, J., Walker, B., Liverman, D., Richardson, K., Crutzen, P., \& Foley, J. A. (2009). Nature, 461, 472-475.

11. Rockström, J., Steffen, W., Noone, K., Persson, A., Chapin, F. S., Lambin, E. F., Lenton, T. M., Scheffer, M., Folke, C., Schellnhuber, H. J., Nykvist, B., de Wit, C. A., Hughes, T., van der Leeuw, S., Rodhe, H., Sörlin, S., Snyder, P. K., Costanza, R., Svedin, U., Falkenmark, M., Karlberg, L., Corell, R. W., Fabry, V. J., Hansen, J., Walker, B., Liverman, D., Richardson, K., Crutzen, P., \& Foley, J. A. (2009). Ecology and Society, 14, 32.

12. Carpenter, S. R. (2008). Proceedings of the National Academy of Sciences USA, 105, 11039-11040.

13. Grzmil, B., \& Wronkowski, J. (2006). Desalination, 189, 261-268.

14. Carpenter, S. R., \& Bennett, E. M. (2011). Environmental Research Letters, 6, 014009.

15. Zhou, Y., Xing, X. H., Liu, Z., Cui, L., Yu, A., Feng, Q., \& Yang, H. (2008). Chemosphere, 72, $290-298$.

16. Stratful, I., Scrimshaw, M. D., \& Lester, J. N. (2001). Water Research, 35, 4191-4199.

17. Blackall, L. L., Crocetti, G. R., Saunders, A. M., \& Bond, P. L. (2002). Antonie Van Leeuwenhoek, 81, 681691.

18. Oehmen, A., Lemos, P. C., Carvalho, G., Yuan, Z., Keller, J., Blackall, L. L., \& Reis, M. A. (2007). Water Research, 41, 2271-2300.

19. Brdjanovic, D., Slamet, A., Van Loosdrecht, M. C. M., Hooijmans, C. M., Alaerts, G. J., \& Heijnen, J. J. (1998). Water Research, 32, 200-208.

20. Zeng, R. J., Lemaire, R., Yuan, Z., \& Keller, J. (2003). Biotechnology and Bioengineering, 84, 170-178.

21. Paul, J. H., \& Sullivan, M. B. (2005). Current Opinion in Biotechnology, 16, 299-307.

22. Breitbart, M., Thompson, L. R., Suttle, C. A., \& Sullivan, M. B. (2007). Oceanography, 20, 135-139.

23. Sharon, I., Battchikova, N., Aro, E. M., Giglione, C., Meinnel, T., Glaser, F., Pinter, R. Y., Breitbart, M., Rowher, F., \& Béjà, O. (2011). ISME Journal, 5, 1178-1190.

24. Sullivan, M. B., Coleman, M. L., Weigele, P., Rohwer, F., \& Chisholm, S. W. (2005). PLoS Biology, 3, e144.

25. Zeng, Q., \& Chisholm, S. W. (2012). Current Biology, 22, 124-128.

26. Li, Q., Yu, Z., Shao, X., He, J., \& Li, L. (2009). FEMS Microbiology Letters, 299, 44-52.

27. Castberg, T., Thyrhaug, R., Larsen, A., Sandaa, R. A., Heldal, M., Van Etten, J. L., \& Bratbak, G. (2002). Journal of Phycology, 38, 767-774.

28. Wilson, W. H., Schroeder, D. C., Allen, M. J., Holden, M. T., Parkhill, J., Barrell, B. G., Churcher, C., Hamlin, N., Mungall, K., Norbertczak, H., Quail, M. A., Price, C., Rabbinowitsch, E., Walker, D., Craigon, M., Roy, D., \& Ghazal, P. (2005). Science, 309, 1090-1092.

29. Pagarete, A., Allen, M. J., Wilson, W. H., Kimmance, S. A., \& de Vargas, C. (2009). Environmental Microbiology, 11, 2840-2848.

30. Monier, A., Pagarete, A., de Vargas, C., Allen, M. J., Read, B., Claverie, J. M., \& Ogata, H. (2009). Genome Research, 19, 1441-1449.

31. Hannun, Y. A., \& Obeid, L. M. (2008). Nature Reviews-Molecular Cell Biology, 9, 139-150.

32. Coderch, L., López, O., Adl, M., \& Parra, J. L. (2003). American Journal of Clinical Dermatology, 4, 107129.

33. Leonardi, G. R., Gaspar, L. R., \& Campos, P. M. B. G. (2002). Anais Brasileiros de Dermatologia, 77, 563569.

34. Zhang, M., Xie, J., Zhou, Q., Chen, G., \& Liu, Z. (2003). Journal of Chromatography, 984A, $173-183$.

35. Lightner, D. V., Redman, R. M., Bell, T. A., \& Brock, J. A. (1983). Journal of the World Mariculture Society, $14,212-225$.

36. Vega-Heredia, S., Mendoza-Cano, F., \& Sánchez-Paz, A. (2012). Transboundary and Emerging Diseases, 59, 95-105.

37. Shike, H., Dhar, A. K., Burns, J. C., Shimizu, C., Jousset, F. X., Klimpel, K. R., \& Bergoin, M. (2000). Virology, 277, 167-177. 
38. Hou, L., Wu, H., Xu, L., \& Yang, F. (2009). Archives of Virology, 154, 547-553.

39. La Fauce, K. A., \& Owens, L. (2009). Journal of Invertebrate Pathology, 100, 111-115.

40. Ramachandran, P. V., \& Ignacimuthu, S. (2013). Applied Biochemistry and Biotechnology, 169, 1774-1789.

41. Chou, M. I., Hsieh, Y. F., Wang, M., Chang, J. T., Chang, D., Zouali, M., \& Tsay, G. J. (2010). Journal of Biomedical Science, 17, 51.

42. Sánchez-Paz, A. (2010). Veterinary Research, 41, 43.

43. Li, F., Li, M., Ke, W., Ji, Y., Bian, X., \& Yan, X. (2009). Virology, 385, 267-274.

44. Liu, W. J., Chang, Y. S., Wang, C. H., Kou, G. H., \& Lo, C. F. (2005). Virology, 334, 327-341.

45. He, F., Ho, Y. F., Yu, L., \& Kwang, J. (2008). BMC Microbiology, 8, 238.

46. Kobelt, D., Aumann, J., Fichtner, I., Stein, U., Schlag, P. M., \& Walther, W. (2010). Molecular Biotechnology, 46, 197-205.

47. Nwe, N., He, Q., Damrongwatanapokin, S., Du, Q., Manopo, I., Limlamthong, Y., Fenner, B. J., Spencer, L., \& Kwang, J. (2006). BMC Microbiology, 6, 16.

48. Londrigan, S. L., Turville, S. G., Tate, M. D., Deng, Y. M., Brooks, A. G., \& Reading, P. C. (2011). Journal of Virology, 85, 2990-3000.

49. Stegmann, T. (2000). Traffic, 1, 598-604.

50. Bush, R. M., Fitch, W. M., Bender, C. A., \& Cox, N. J. (1999). Molecular Biology and Evolution, 16, 14571465.

51. Smith, G. E., Summers, M. D., \& Fraser, M. J. (1983). Molecular and Cellular Biology, 3, 2156-2165.

52. Mitsudome, T., Xu, J., Nagata, Y., Masuda, K., Morokuma, D., Li, Z., Mon, H., Lee, J. M., \& Kusakabe, T. (2014). Applied Biochemistry and Biotechnology, 172, 3978-3988.

53. Duncan, T. V. (2011). Journal of Colloid and Interface Science, 363, 1-24.

54. Jianrong, C., Yuqing, M., Nongyue, H., Xiaohua, W., \& Sijiao, L. (2004). Biotechnology Advances, 22, 505518.

55. Logothetidis, S. (2012). In S. Logothetidis (Ed.), Nanostructured materials and their applications (pp. 1-22). Berlin, Heidelberg: Springer.

56. (2010) Nanotechnology: a realistic market assessment. Available from www.bccresearch.com/report/ nanotechnology-market-applications-products-nan031e.html. Accessed 8 March 2013.

57. Wang, L., Lane, L. C., \& Smith, D. L. (2001). Protein Science, 10, 1234-1243.

58. Fischlechner, M., \& Donath, E. (2007). Angewandte Chemie, 46, 3184-3193.

59. Liu, Y., Tan, J., Thomas, A., Ou-Yang, D., \& Muzykantov, V. R. (2012). Therapeutic Delivery, 3, $181-194$.

60. Amalfitano, A., Begy, C. R., \& Chamberlain, J. S. (1996). Proceedings of the National Academy of Sciences USA, 93, 3352-3356.

61. Spilane, C., Verchot, J., Kavanagh, T. A., \& Baulcombe, D. C. (1997). Virology, 236, 76-84.

62. Welch, S. K., Jolie, R., Pearce, D. S., Koertje, W. D., Fuog, E., Shields, S. L., Yoo, D., \& Calvert, J. G. (2004). Veterinary Immunology Immunopathology, 102, 277-290.

63. Engelhardt, T., Kallmeyer, J., Cypionka, H., \& Engelen, B. (2014). The ISME Journal, 8, 1503-1509.

64. Suttle, C. A. (2007). Nature Reviews-Microbiology, 5, 801-812. 